\title{
The Juridical Relations in the Criminal Process Between Republic of Italy and Republic of Albania
}

\author{
Ermira Tafani \\ Prosecution Office, Elbasan, Albania \\ Lecturer in the University "Aleksandër Xhuvani", Elbasan, Albania \\ Doctoral School, European University of Tirana, Albania \\ tafani_ermira@yahoo.com
}

\section{Doi:10.5901/ajis.2013.v2n9p494}

\begin{abstract}
During the history Italy and Albania, being two neighboring states have had good mutual relations between them. After the democratic changes in Albania in 1991, a lot of Albanians emigrated in Italy. This was accompanied by wide relations between Italy and Albania in the juridical criminal process, as in all areas of life. These relations are of great interest to be studied indepth, taking into consideration the free movement of the citizens from one country to another, which brings about the breaking of barriers and boarders among states. This study tends to analyze, the Albanian legal basis of the juridical relations in the criminal process with Italy, including: the new internal laws, a series of international acts that Albania has ratified and agreements with Italy. This analysis will be based on a detailed observation, using scientific descriptive and comparative research methods of Albanian and Italian legislation, concluding that Italy and Albania have good legal basis on the cooperation for an effective fight against crime, giving justice and punishment to the authors of criminal acts.
\end{abstract}

Keywords: law, juridical relations, cooperation, international legal act, criminal process, agreements.

\section{Introduction}

The formation of modern and sovereign states gained their identity after the First World War and brought about the development of cooperation between different countries, among others, in the field of Law. Jurisdictional relations with foreign states in the criminal process are a special area where the cooperation among different states is obviously seen. These are of great interest to be studied in-depth, taking into consideration the free movement of the citizens from one country to another, which brings about the breaking of barriers and boarders in between states, especially between two neighboring states as Italy and Albania are.

During the history Italy and Albania have had good mutual relations between them. After the democratic changes in Albania in 1991, a lot of Albanians emigrated in Italy. This was accompanied by wide relations between Italy and Albania in the juridical criminal process, as in all areas of life. Jurisdictional relations in the criminal process of Albania with Italy as a foreign state are exercised in accordance with the requirements, procedures and from the institutions foreseen by law. Here we may mainly mention: Extradition, International Requests and the Execution of Foreign Criminal Sentences. This study tends to analyze the steps that Albania has followed through years in the jurisdictional relations in the criminal process with Italy, aiming to show that these two states have good legal basis on the cooperation for an effective fight against crime, giving justice and punishment to the authors of criminal acts. This analysis will include the legal basis of Republic of Albania and Republic of Italy in the field of jurisdictional relations with foreign countries in the criminal process.

\section{A short historic overview on relations between Italy and Albania}

During the history Italy and Albania, being two neighboring states have had good mutual relations between them. These relations are as ancient as our two countries are and have witnessed a steady binomial interest.

Rome and Benedict had economical, political and cultural relations with Illyrian Sate. Skanderbeg had good relations with Alfonse the $5^{\text {th }}$ of Napoli. Hundreds and thousands of Arbers persecuted by Osmans after the death of Skanderbeg emigrated in Italy. It is well known the contribution of Italy in London's Conference for the independence of Albania. After the Independence and the formation of the Albanian State in 1912, Italy was one of the first states which 
had diplomatic relation with the government of Prince Vid. After an interruption of relations during the First World War, they restarted in 1920 and would continue to expand during the King Zog government until April 7, 1939. During this period the Italian Culture had a great impact to Albanian people. All the new Albanian laws, among which the Criminal Laws, were created upon the model of the Italian laws.

During the Second World War (1939 - 195) Albania was invaded by Italian fascists. In February 1947 in Paris it was signed the Peace Treaty between Italy and Albania. The diplomatic relations restarted In May 1949. Since the first years after the war, Italian Governments declaimed fascist aggression of April 7, 1939, considering it only a historic fact and have known the sovereignty and he existing borders of Albania. During the communist regime Albania was isolated. During 80 's it is seen a development of the relations between the two countries, especially commercial and cultural relations.

After the democratic changes of Albania, lots of Albanian emigrated to Italy during $1991-1992$. This is followed by active relationship between Italy and Albania. In the beginning of democracy in Albania, Italy was evidenced as one of the strategic partners of Albania, assisting and contributing in the reformation of the institutions, economy and the consolidation of the state of law. The actual Criminal Laws in Albania are based on the model of the Italian Laws, besides other European developed countries. The relations between Italy and Albania are widespread in all the areas of life, as: politics, economics, law, etc, which are followed with the ratification of a lot of mutual agreements.

\title{
3. The development of the juridical relations in the criminal process in Albania
}

The development of the Albanian State, and Criminal Law as part of it, has been similar to those around the world.

\begin{abstract}
[Being a product of the development of human society, born and developed together with the state, the criminal law has historic character and is subject to continuous changing process,... It always takes that form and content that respond to the interests of the social system of the corresponding historical era.]1

Original version:

(Duke qënë produkt i zhvillimit të shoqërisë njerëzore, e lindur dhe e zhvilluar sëbashku me shtetin, e drejta penale ka karakter historik dhe i nënshtrohet procesit të përpunimit e të ndryshimit të vazhdueshëm,... Ajo merr kurdoherë atë formë e përmbajtje që u përgjigjet interesave të sistemit shoqëror të epokës historike përkatese.)
\end{abstract}

The beginnings of the Criminal Law in Albania as a branch of the Law in general are closely connected with the formation of the Independent Albanian State and the Vlora Government in 1912. Due to the obstacles which came as a result of the First World War, territorial claims of Albania from some foreign states and the disruption within the country, the efforts of Vlora Government for the organization of the new Albanian State were unsuccessful until 1920.

[The full meaning of the concept of Criminal Law system in Albania can be mentioned only after the approval of the Statute of Lushnja (1920) and the Extended Statute of Lushnja (1922), continuing to the year 1939.]2

Original version:

(Për sistem të drejtësisë kriminale në Shqipëri, në kuptimin e plotë të fjalës, mund të flitet vetëm pas miratimit të Statutit të Lushnjës (1920) dhe Statutit të zgjeruar të Lushnjës (1922) e në vazhdim deri në vitin 1939.)

When King Zog came to power, during the period 1920 - 1928, the organization of justice system was made possible, and the legal framework was completed as well. These were accomplished through the approval of some important laws, among which were the Criminal Code, and the Criminal Procedure Code. These laws were based on the models of European countries laws.

In the period between the two World Wars, the beginnings of jurisdictional relations between different countries started in the world. It's exactly in this period that the juridical relations with foreign states in the criminal process were introduced to Albania too, where among other things some agreements with other states were signed for the extradition of the criminals.

After the Second World War, with the establishment of the totalitarian communist regime, Albania was in complete isolation, following the principle 'relying on our own forces'. The Constitution of People's Socialist Republic of Albania,

\footnotetext{
${ }^{1}$ Muçi, Sh. (2007), E drejta penale (Pjesa e Përgjithshme) (Criminal Law - General part), Botimet Dudaj, Tirana, pg.12

2 Elezi, I. (2001), Vështrim i Shkurtër Historik i Drejtësisë Penale në Shqipëri dhe sfidat para saj (Short Historic Overview of Criminal Law in Albania and its Challanges), seen on http://drejtesiashqiptare.com/, accessed on April 20, 2011
} 
Criminal Codes and in the Criminal Procedure Codes of this period didn't contain or foresee anything connected as far as jurisdictional relations with foreign countries were concerned.

The democratic changes that happened at the beginning of the 90's in Albania and the transition from a totalitarian system to a democratic system marked a complete turn in the history of the Albanian State and its institutions. The democratic orientation of the state is followed by several reforms in all areas of life, part of which was Criminal Law. In 1995 the new Criminal Code and the new Criminal Procedure Code were approved, which have an important place in the jurisdictional relations with foreign states in criminal process. These codes are built according to the models of contemporary criminal codes of some European democratic states (mainly Italy, France and Germany). For the time they were approved, those codes were to some extends according to international standards.

After the democratic changes of 1990, the opening of Albania, the constitutional changes of 1991, followed by other general legal reforms, brought about the ratification of several International Acts in the field of international relations with other states, like convents, treaties, bilateral or multilateral agreements, etc.

\section{The development of the juridical relations in the criminal process between Italy and Albania}

Albania has ratified several International Acts in the field of international relations with other states, where Italy as a member of European Union is part as well, as follows:

4.1. Convention of European Council "On Extradition" of December 13, 1957 and its two additional protocols of October 15, 1975 and March 17, 1978 (ratified with law 8322, date 09.04.1998); the third additional protocol of Strasbourg November 10, 2010; the fourth additional protocol of September 20, 2012 (ratified with law 10426, date 06.06.2011);

4.2. Convention of European Council "On Mutual Legal Assistance in Criminal Matters" of April 20, 1959 and its additional protocols of March 17, 1978 and August 11, 2001 (ratified with law 8498, date 29.06.1999);

4.3. European Convention on "The International Validity of Criminal Judgments" of May 28, 1970 (ratified with law 9068, date 15.5.2003);

4.4. Convention of European Council "On the Transfer of the Proceedings in Criminal Matters" of May 15, 1972 (ratified with law 8497, date 29.06.1999);

4.5. Convention of European Council "On the Transfer of Sentenced Persons" of March 21, 1983 and its additional protocol of December 18, 1999(ratified with law 8499, date 29.06.1999).

4.6. Despite these conventions, with the law 9590 date 27.07.2006 Albania ratified the "Stabilization and association agreement between the Republic of Albania and the European Communities and their states". This is an important agreement in the framework of the stabilization and association of the countries of Eastern Europe to a stabilized Europe where a European Country has the most important role. Through this agreement the parties had the aim to strengthen the cooperation in a wide range of areas, particularly in justice. One of the commitments of Albania through this agreement is the development of common interest projects, particularly those related to fight against organized crime, corruption, money laundering, illegal migration and trafficking. To fulfill this commitment Albania has ratified a series of bilateral or multilateral agreements on cooperation in these areas, which affect the issues on extradition, international relations in prosecuting and judging the criminal matters, among them: The agreement between the governments of countries which are part of the Black Sea Economical Cooperation (2006); Macedonia (1998, 2004); Spain (2009); Leetonia (2010), Belgium (2011), etc.

\footnotetext{
[All these treaties follow the same pattern: they contain an agreed definition of the prohibited conduct, oblige contracting states to criminalize the conduct within their legal systems, provide for certain heads of criminal jurisdiction and ensure the mutual extradition of alleged offenders.]3
}

${ }^{3}$ Cassese, A., Gaeta, P., Baig, L., Fan, M., Gosnell, C., Whiting, A. (2012), Cassese's International Criminal Law, 3rd ed., Oxford University Press, pg. 19 
4.7 Italy and Albania have signed some agreements in fulfillment of the European Conventions, as follows:

4.7.1 Additional agreement of the European Convention "On the Transfer of Sentenced Persons" of March 21, 1983. It is signed in Rome, in April 24, 2002, with the aim to intensify and facilitate cooperation in relations between the two countries in the implementation of this Convention, considering suitable to fulfill some points of the Convention, with the aim to extend the implementation with other forms of execution of criminal judgments (In Albania it is ratified with law 9169, date 22.1.2004).

4.7.2 Cooperation agreement in fight against crime which is ratified in Albania with law 9799 date 09.10.2007. This agreement is signed on the principles of mutual respect, equality and sovereignty, in order to further develop and consolidate the friendly relations existing between the two countries; aware that the criminal phenomena and related prosecuted crime affecting every sector in both countries, jeopardizing public safety and security, inviolability and physical well-being of their citizens; bearing in order to contribute actively in the fight against crime in all its forms; confirming mutual interest in strengthening understandings to become more efficient and systematic fight against organized crime, migration flows of illegal immigrants, trafficking of narcotics and psychotropic substances, trafficking and other illegal acts between Italy and Albania.

4.7.3 Additional agreement on the European Convention on Extradition of the December 13, 1957 and the European Convention "On Mutual Legal Assistance in Criminal Matters" of April 20, 1959, which aims to facilitate the implementation of these conventions; underlining the common interest to have a quick and efficient mutual legal assistance; to complete and include relevant relationships in the field of legal assistance on extradition, in accordance with the acquits of the European Union on this issue; expressing the confidence in the structure and functioning of the respective legal regulations and the ability of the Parties to ensure the same processes.

\section{The Juridical Concept of the Relations with Foreign Countries in the Criminal Process}

International relations, among other things, include relations among different states. These relations are studied by the theory of the Law, thus creating a separate discipline, which is defined as:

[The discipline that gained its identity after the First World War, which studies the interactions among states ... $]^{4}$

Original version:

(Disiplina që fitoi identitetin e vet pas luftës së parë botërore, që studion ndërveprimet midis shteteve...)

Legal issues for regulating relations among different countries cannot be limited within the national framework, but they have always acquired an international perspective.

[The principal reason of this new dimension is the increasingly great and strong will of states to cooperate with each other in mutual plan and beyond in function of peace and international security and the guarantee of a sustainable development in all the sectors of life in the country. $]^{5}$

Original Version:

(Arsyeja kryesore e këtij dimensioni të ri të saj është vullneti gjithnjë e më i madh i shteteve për të bashkëpunuar me njëri - tjetrin në planin dypalësh dhe më gjerë, ne funksion të paqes dhe sigurisë ndërkombëtare dhe garantimit të një zhvillimi sa më të qëndrueshëm në të gjithë sektorët e jetës së vendit.)

In the framework of globalization of the world, the cooperation among states in the field of International Criminal Law, as in other fields of Law, has been developing with every passing day. This instrument allows different states to organize the "joint repression of certain criminal offences, more specifically those that damaged their collective interests and had a strong transnational dimension."The jurisdictional relations with foreign states in the criminal process are exercised in accordance with the requirements, procedures and from institutions foreseen by law. They are a good possibility for interaction among various countries in criminal field, having as the final aim the effective fight against crime,

\footnotetext{
${ }^{4}$ Uka, Nj. (2011), Fjalor i drejtësisë (Justice Vocabulary), "ILARI" P.F., Tirana, pg.437

${ }^{5}$ Zaganjori, Xh. (2012), Jurisprudencë dhe praktikë ndërkombëtare (International Jurisprudence and Practice), Adelprint, Tirana

${ }^{6}$ Cassese, A., Gaeta, P., Baig, L., Fan, M., Gosnell, C., Whiting, A. (2012), Cassese's International Criminal Law, 3rd ed., Oxford University Press, pg. 18
} 
giving justice and criminalizing the authors of criminal acts, which is one of the duties of the criminal legislation. They are developed in two directions:

Proceeding (prosecution and judging) of criminal acts;

The execution of criminal Court decisions everywhere in the world.

\subsection{Proceeding of criminal acts}

As a result of the extension of free movement of the citizens from one state to another, it often happens that any person in his/her everyday life may commit a criminal act in the territory of a foreign state. According to criminal legislation all over the world, the foreign citizens are responsible for the criminal acts done by them.

Article 7 of Criminal Code of Republic of Albania foresees:

[The foreign citizen, who commits a criminal act in the territory of the Republic of Albania, is responsible for this criminal act based on the criminal Law of the Republic of Albania]7

Original version:

(Shtetasi i huaj, që kryen vepër penale në territorrin e Republikës së Shqipërisë, përgjigjet në bazë të ligjit penal të Republikës së Shqipërisë.)

In the same time, in the articles 3, 6 of Procedural Criminal Code of Italy, it is foreseen that all the persons: Italian citizens, foreigners, without citizenship, or refugees, who are in the Italian territory, are subjects of the Italian Criminal Law.

On the other hand, committing a criminal act may be presented in various complex forms and more organized cooperation, covering several states and brings as a necessity the carrying out of investigating actions at the same time from various states. This could be realized only through jurisdictional relationships among various states in the criminal process, which is expressed in the mutual legal assistance, foreseen in the European Convention on Mutual Assistance in the Criminal Matters.

[The international exchange of evidence in criminal matters through formal mutual legal assistance arrangements is a fairly recent phenomenon. Realizing that participation in formal arrangements would provide prosecuting authorities with increased access to evidence located abroad. States have become increasingly willing to negotiate mutual legal assistance treaties. $]^{8}$

During the proceeding of criminal matters, the jurisdictional relations with foreign authorities are based in the national legislation and international acts, as: treaties agreements, etc.

[During the first decades of the twentieth century, treaties for the repression of crimes such as counterfeiting, slavery, the traffic in women and children began to emerge and continued to be concluded throughout the century up until the present day, for example to fight 'terrorist' crimes, money laundering, corruption, and so on..$^{9}$

International acts are obligatory for the state parties, even if the national legislation foresees differently. Once the international act is ratified by a state, the inner legislation should be changed in accordance with the international acts.

[A number of international treaties, which address international (or transnational) crimes, oblige the State Parties to investigate and prosecute the offence in question, or to extradite suspects to another State Party. $]^{10}$

The mutual legal assistance during the proceedings of the criminal acts is made by international requests (rogatory requests) from one country to another. These are mechanisms used by different states to reciprocity cooperate in investigating the criminal matters, to obtain evidences for a certain criminal matter from another state. This can be done with the consensus of the two states, which are parts of these requests. The rules and the conditions to be fulfilled by an

\footnotetext{
${ }^{7}$ Law 7895 date 27.01.1995, "Kodi Penal i Republikës së Shqipërisë" (Criminal Code of Republic of Albania), Tirana

${ }^{8}$ Bantekas, I., Nash, S. (2003), International Criminal Law, 2nd ed., CAVENDISH, London, UK, pg. 231

${ }^{9}$ Cassese, A., Gaeta, P., Baig, L., Fan, M., Gosnell, C., Whiting, A. (2012), Cassese's International Criminal Law, 3rd ed., Oxford University Press, pg. 17

${ }^{10}$ Cryer, R., Friman, H., Robinson, D., Wilmshurst, E., (2010) "An introduction to International Criminal Law and Procedure", 2nd ed., Cambridge University Press, Cambridge, UK, pg. 69
} 
international request are foreseen in the inner legislation of the states (mainly, Procedure Criminal Code) and in the mutual agreements between states.

\subsection{The execution of criminal Court decisions}

The proceeding and the criminal sentence of foreign citizens is often done in their absence, thus the execution of the criminal court decisions from the states which give this sentence, is impossible. This way, it is logical that the execution of the criminal sentence has to be done by the country of residence of the convicted person. The execution of criminal Court decisions is connected with such institutes of law, as: "Execution of foreign criminal Court decisions", "Recognition of foreign criminal Court decisions" and "Extradition". The "Extradition" is an interstate mechanism to submit a person in a certain state territory to another state, which is criminally proceeding him.

The conditions and the procedure of the execution of foreign criminal Court decisions and extradition are foreseen by inner legislation and the other International Acts, mentioned above.

\section{The Legal Basis of Jurisdictional Relations in the Criminal Process}

The International Criminal Law is composed of jus gentium and jus inter gentes. Referring to these main sources of the International Law, the Constitution of Republic of Albania ${ }^{11}$ foresees that:

- The Law is the basis and limits of state activity (article 4/1);

- Republic of Albania applies the binding International Law (article 5);

- The normative dispositions, which act in the entire territory of the Republic of Albania are: the Constitution, the ratified international agreements, laws, etc. (article 116)

On the other hand, the Constitution of Republic of Italy foresees that: Italian laws conform to the generally recognized principles of international law (article 10, point 1).

In this way, the constitutions of both countries accept the principle of prevalence of the international conventions and the international law. This fundamental constitutional principle, at the same time is expressed in the article 696 of the Italian Procedure Criminal Code and in the article 1/a of Albanian Criminal Code, where the bases of the criminal legislation are foreseen:

[The Criminal Code is based on the Constitution of the Republic of Albania, general principles of the International Criminal Law, and international acts ratified by the Albanian State.

The criminal legislation is composed by this Code and other laws which foresee criminal acts. $]^{12}$ Original version:

(Kodi Criminal bazohet në Kushtetutën e Republikës së Shqipërisë, parimet e përgjithshme të së drejtës criminale ndërkombëtare, si dhe në marrëveshjet ndërkombëtare të ratifikuara nga shteti shqiptar.

Legjislacioni criminal përbëhet nga ky Kod dhe ligje të tjera që parashikojnë vepra criminale.)

Based on this, the international relations of Albanian State with other countries in the criminal process are regulated with a series of dispositions of inner Albanian Criminal Law, and the international acts as well, like agreements, conventions, etc.

\subsection{The National Legal Basis in Albania comparing with the Italian Law}

Parts of the inner legislation of the Republic of Albania that regulates the jurisdictional relations of Albania with other foreign countries in the criminal process are:

- The Constitution

- The Criminal Code

- The Criminal Procedure Code

- Other Laws

${ }^{11}$ Law 8417 date 21.10.1998 "Kushtetuta e Republikës së Shqipërisë" (The Constitution of Republic of Albania), Tirana

12 Law 7895 date 27.01.1995, "Kodi Penal i Republikës së Shqipërisë" (Criminal Code of Republic of Albania), Tirana 


\subsection{The Constitution}

After the change of the political system in Albania, the democratic principles of the state of Law firstly were embodied in the law 7491, date 29.04.1991, "For the main constitutional dispositions" and the law 7561 date 29.04.1992 "For some changes and supplements in the Law 7491 date 29.04.1991 /For the main constitutional dispositions/", which served as the basis for the Constitution in use, approved in the year 1998. These laws gave an end to the long-term isolation of Albania and opened the road towards the development of jurisdictional relations of Albania with foreign states. The fundamental principles of the Albanian Constitution are similar to those of other democratic developed countries, where Italy takes part.

The Constitution of the Republic of Albania is the highest law. This is foreseen in its article 4/1. Judging from this fact, all juridical - criminal norms are based on the main constitutional principles, thus making the Constitution the basic source of the Criminal Law, as well as for all the Albanian Law in general, as a whole. It is foreseen the same in the Constitution of Republic of Italy, which became in force the $1^{\text {st }}$ of January 1948 and further constitutional laws.

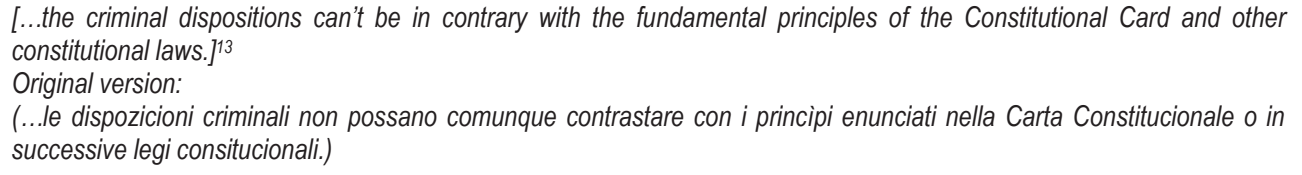

A lot of norms of the Constitution of Republic of Albania are directly connected with the International Law and the Criminal Law, among which, even with the jurisdictional relations with foreign states in the criminal process. The same happens in the Constitution of Republic of Italy.

The article 39/2 of the Albanian Constitution foresees, that extradition might be allowed only in those matters when it is foreseen in international agreements, in which the Republic of Albania is a party, and only with a court decision. The article 10 of Italian Constitution foresees that the extradition of a foreigner for political offences is not admitted.

The article $121 / \mathrm{b}$ foresees that the ratification and denouncing of international agreements from the Republic of Albania is done through the law, in matters when they have to do with the freedom and human rights, and when they have to do with the obligations of the citizens, which can be found in the criminal process too.

The article 122 foresees, among other things, that each ratified international agreement is part of the inner system and is implemented in a direct way or is ratified by law. A ratified international agreement by law has priority over the laws of the country. In the Italian Constitution, the article 10 foresees: Italian laws conform to the generally recognized acts of international law. The legal status of foreigners is regulated by law in conformity with international provisions and treaties.

\subsection{Criminal Code}

The basic principles upon the Criminal Law are foreseen in the general part of the Criminal Code of Albania. Here are also included the general principles of the jurisdictional relations with foreign countries in the criminal process. Meanwhile, the legal procedures of these relations are regulated by the Criminal Procedure Code and other special laws. The article $1 / a$ of the Criminal Code defines that, this code is based on general principles of the international Criminal Law, and on the international agreements ratified by the Albanian State. The Criminal Code foresees regulations even for the implementation of the Criminal Law for criminal acts committed by Albanian citizens in foreign territories (article 6/2); for the implementation of the Criminal Law for criminal acts committed by foreign citizens (articles 7 and $7 / a$ ), or criminal acts committed by a person without citizenship (article 8), and for persons that have immunity (article 9).

Concerning the jurisdictional relations with foreign countries in the criminal process, article 10, "The power of criminal sentences of foreign courts" and article 11, "Extradition" of the Criminal Code, define: 
[The criminal sentences given by the foreign courts for the Albanian citizens that prove the commitment of a criminal act are valid in Albania within the boundaries of the Albanian Law, when it is not foreseen differently in bilateral or multilateral agreements ...

Extradition may be allowed only when it is foreseen in the international agreements in which the Republic of Albania is a party .... $]^{14}$

Original version:

(Vendimet penale të dhëna nga gjykatat e huaja ndaj shtetasve shqiptarë që vërtetojnë kryerjen e një vepre penale, kur nuk është parashikuar ndryshe nga marrëveshjet dy ose shumpalëshe, vlejnë në Shqipëri brenda kufijve të ligjit shqiptar...

Ekstradimi mund të lejohet vetëm kur është parashikuar shprehimisht në marrëveshjet ndërkombëtare në të cilat Republika e Shqipërisë është palë...)

\subsection{The Criminal Procedure Code}

The Albanian Criminal Procedure Code is the basic law that regulates the jurisdictional relations with foreign countries in the criminal process. In its general dispositions, exactly in article 10, it is foreseen:

[The relations with foreign authorities in the criminal area are regulated by international agreements, accepted by the Albanian State, by generally accepted principles and norms of the International Law, and by the dispositions of this Code as well. $]^{15}$

Original version:

(Marrëdhëniet me autoritetet e huaja në fushën penale rregullohen nga marrëveshjet ndërkombëtare, të pranuara nga shteti shqiptar, nga parimet dhe normat përgjithësisht të pranuara të së drejtës ndërkombëtare, si dhe dispozitat e këtij Kodi.)

In its title $X$, the Criminal Procedure Code has a series of dispositions where the jurisdictional relations with foreign authorities are foreseen.

The first Chapter of this Title defines regulations on 'extradition', not only to another country (articles 488 - 503), but also from another country (article 504). Article 488 defines the meaning of extradition, as: "Giving a person to a foreign state to execute a decision sentenced with jail or the execution of an act that certifies his/her prosecution for a criminal act ..." In this code are defined: the procedures that should be followed by the organs of justice in the matter of extradition; the conditions when this extradition is allowed; the coercive measures and seizures in matters of extradition; and the expenses of extradition as well.

Following, in the second Chapter, the international requests are foreseen, not only from another country (articles 505508), but also to another country (articles 509-511). In the meaning of these dispositions, the international requests consist of interstate actions, connected with the communication of acts, announcements and gathering the data in the criminal process. These dispositions define: matters when could be proceeded with an international request directed to foreign authorities; competences of the Ministry of Justice, which is the only organ through which requests directed to foreign authorities are sent and vice versa; and the validity of the acts taken from the international requests.

Lastly, in the third chapter, the execution of the foreign criminal Court sentences (articles 512-518) is foreseen, and also the execution of Albanian criminal sentences in other countries (articles 519-523) is foreseen as well. In these dispositions are defined: legal procedures and competent organs for the acknowledgement of the criminal sentences; the criteria that should be fulfilled for the acknowledgement of criminal sentences; obligatory coercive measures that could be undertaken during the process of the acknowledgement of criminal sentences; the way of deciding the punishments; and the way of their execution.

\footnotetext{
${ }^{14}$ Law 7895 date 27.01.1995, "Kodi Penal i Republikës së Shqipërisë" (Criminal Code of Republic of Albania), Tirana

${ }^{15}$ Law 7905 date 05.04.1995 "Kodi i Procedurës Penale i Republikës së Shqipërisë" (Criminal Procedure Code of Republic of Albania), Tirana
} 
The Italian Criminal Code regulates the international relations with foreign states in the criminal process in its $11^{\text {th }}$ title. In its general disposition, article 696, among others, it is foreseen that the extraditions, the international requests, the effects of the foreign criminal court decisions and other relations with foreign authorities in the criminal process, are regulated by the norms of European Convention of judicial assistance of Strasbourg (20 th of April 1959); other international acts ratified by the state and by the general principles of International Criminal Law. This article expresses the principle of prevalence of the international conventions and the international law.

The first Chapter of this Title defines regulations on 'extradition' to and from another country (articles 697 - 723). In this code there are defined: the meaning of extradition, the procedures that should be followed by the organs of justice in the matter of extradition; the conditions when this extradition is allowed; the coercive measures and seizures in matters of extradition; and the expenses of extradition as well.

The second Chapter of this title regulates, the international rogatory requests not only from another country (articles 723 - 726), but also to another country (articles 727 - 729). Based on the article 723 of Italian Criminal Procedure Code, the rogatory requests of a foreign state are permitted for communications, notifications and evidences. They must fulfill the condition to not violate the sovereignty, the security and other essential interests of the state. These dispositions define: the matters when could be proceeded with a rogatory request; conditions that they must fulfill; the cases when a rogatory request can be refused, their procedures; and the validity of the acts taken from the rogatory requests. In the Italian legislation it is foreseen that the Ministry of Justice is the only organ through which requests directed to foreign authorities are sent and vice versa.

The third chapter regulates the effects of the foreign criminal Court sentences (articles $730-741$ ) and also the execution of Italian criminal sentences in other countries (articles 742 - 746). In these dispositions are defined: legal procedures and competent organs for the acknowledgement of the criminal sentences; the criteria that should be fulfilled for the acknowledgement of criminal sentences; obligatory coercive measures that could be undertaken during the process of the acknowledgement of criminal sentences; the way of deciding the punishments; and the way of their execution.

Based on the analysis of the Laws of both countries, it is noted that they have similar dispositions on international relations in the criminal process, in general dealt with: the structure of the dispositions; the juridical concepts; the sorts of mutual assistance, which consists in: extradition, international (rogatory) requests, recognition of foreign criminal Court decisions and execution of foreign criminal Court decisions; the limitations; the procedures and the organs which can exercise these kind of actions. The Laws of both countries are in full coherence with the European Conventions in the field of jurisdictional relations in the criminal process (see part 3) and other international acts.

\section{Conclusions}

- During the history Italy and Albania have had good wide mutual relations between them, which is expressed in the area of Law as well.

- Jurisdictional relations with foreign states in the criminal process are a special area where the cooperation among different states is obviously seen. It has a greater importance taking into consideration the free movement of the citizens from one country to another, which brings about the breaking of barriers and boarders in between states, especially between two neighboring states as Italy and Albania are.

- Italy and Albania have good legal basis on the cooperation for an effective fight against crime, giving justice and punishment to the authors of criminal acts.

- The legislations of both these countries are similar, in the same time in full coherence with the European Conventions and all other international acts in the field of jurisdictional relations in the criminal process

\section{References}

Codice di Procedura Criminale

Law 7491 date 29.04.1991 "For the main constitutional dispositions", Tirana, Albania

Law 7895 date 27.01.1995 "Criminal Code of Republic of Albania", Tirana, Albania

Law 7905 date 05.04.1995 "Criminal Procedure Code of Republic of Albania", Tirana, Albania 
Law 8322 date 09.04.1998 "On the ratification of the European Council Convention /On extradition/ and its two additional protocols", Tirana, Albania

Law 8417 date 21.10.1998 "The Constitution of Republic of Albania", Tirana, Albania

Law 8497 date 29.06.1999 "For the ratification of European Council of Europe /For the transfer of proceedings of criminal matters/", Tirana, Albania

Law 8498 date 29.06.1999 "For the ratification of the European Council Convention "On mutual legal assistance in the criminal field", Tirana, Albania

Law 8499 date 29.06.1999 "For the ratification of the European Council Convention "On the transfer of convicted persons", Tirana, Albania

Law 8733 date 24.01.2001 "For some additions and changes in law 7895 date 27.01.1995 /Criminal Code of Republic of Albania", Tirana, Albania

Law no.10039, date 22.12.2008 "For juridical help", Tirana, Albania

Law 10193, date 03.12.2009 "For the jurisdictional relations with foreign authorities in criminal matters", Tirana, Albania

Albanian Helsinki Committee (2006), Report on Human Rights in Albania (1997 - 2003), Tirana, Albania

Bantekas, I., Nash, S. (2003), International Criminal Law, 2nd ed., CAVENDISH, London, UK

Cassese, A. (2008), International Criminal Law, 2nd ed., Oxford University Press, Oxford, UK

Cassese, A., Gaeta, P., Baig, L., Fan, M., Gosnell, C., Whiting, A. (2012), Cassese's International Criminal Law, 3rd ed., Oxford University Press, Oxford, UK

Chiavario, M. (2007), Diritto Processuale Criminale (Profilo institucionale), 3a ed., UTET, Torino, Italy

Conso, G., Grevi, V. (2006), Compendio di Procedura Criminale, 3a ed., CEDAM, Padova, Italy

Cryer, R., Friman, H., Robinson, D., Wilmshurst, E. (2010), An introduction to International Criminal Law and Procedure, 2nd ed. Cambridge University Press, Cambridge, UK

Elezi, I. (2001), Vështrim i Shkurtër Historik i Drejtësisë Penale në Shqipëri dhe sfidat para saj (Short Historic Overview of Criminal Law in Albania and its Challanges), seen on http://drejtesiashqiptare.com/, accessed on April 20, 2011

Elezi, I., Kaçupi \& S., Haxhia, M. (1999), Komentar i Kodit Penal të Republikës së Shqipërisë (Comentary on Criminal Code of Albania), SHBLU, Tirana, Albania

Muçi, Sh. (2007), E drejta Penale (Pjesa e Përgjithshme) (Criminal Law - General part), Botimet Dudaj, Tirana

Riz, R. (2006), Lineamenti di diritto criminale (Parte Generale), 5a ed., CEDAM, Padova, Italy

Xhafo, J. (2009), E drejta penale ndërkombëtare (International Criminal Law), Shtëpia Botuese Geer, Tirana

Uka, Nj. (2011), Fjalor i drejtësisë (Justice Vocabulary), "ILARI" P.F., Tirana, Albania

Zaganjori, Xh. (2012), Jurisprudencë dhe praktikë ndërkombëtare (International Jurisprudence and Practice), Adelprint, Tirana, Albania

http://conventions.coe.int

http://drejtësiashqiptare.com/

http://en.wikipedia.org/wiki/History_of_Albania

http://legislationline.org

http://www.ambalbania.it

http://www.librarialigjore.org 